\title{
Quantitative Determination of Antibody to Capsular Polysaccharide in Infection

\author{
with Type III Strains of Group B Streptococcus
}

\author{
Carol J. Baker, Dennis L. Kasper, Ira B. Tager, Abel Paredes, Susan Alpert, \\ William M. MCCORMACK, and Diana GorofF
}

From the Departments of Pediatrics, Microbiology, and Immunology, Baylor College of Medicine, Houston, Texas 77030; the Channing Laboratory and the Departments of Medical Microbiology and Medicine, Boston City Hospital, Boston, Massachusetts 02118; and the Department of Medicine, Harvard Medical School, Boston, Massachusetts 02115

\begin{abstract}
A B S TRACT The development of antibody in response to invasive infection with type III strains of group B Streptococcus was studied in sera from 31 infants and 4 adults by means of a quantitative radioactive antigen-binding assay. Low concentrations of antibody were consistently found in the acute sera of patients who developed clinical illness. Although adults with puerperal sepsis and infants with bone or joint infection uniformly demonstrated significant rises in serum antibody concentration after recovery, much lower levels of antibody were detected in convalescent sera from infants recovering from meningitis or sepsis.

The median antibody concentration in sera from 43 parturients with type III strains of group B Streptococcus isolated from vaginal cultures whose neonates failed to develop symptomatic disease was significantly greater than that in sera from 29 mothers of infants with invasive, type III, group B streptococcal infection. Study of paired maternal and cord sera demonstrated a significant correlation between the antibody concentration in a mother's serum and that in her neonate.
\end{abstract}

Dr. Kasper is the recipient of Research Career Development Award 1 K04 AI00126 from the National Institute of Allergy and Infectious Diseases.

Address reprint requests to Dr. Baker, Department of Pediatrics, Baylor College of Medicine, Houston, Tex. 77030.

Received for publication 25 October 1976 and in revised form 19 January 1977.

\section{INTRODUCTION}

The group B Streptococcus has become an agent isolated frequently from neonates and young infants with serious infections. Among infants who have meningitis, type III strains of group B streptococci predominate $(1,2)$. The apparent tropism of group B streptococcal strains possessing the capsular type III polysaccharide for the meninges of infants is unexplained $(3,4)$, but chemical constituents in these bacteria do not appear to be responsible for this phenomenon. More than $70 \%$ of the cerebrospinal fluid isolates from neonates with meningitis are type III, group B streptococci or strains of Escherichia coli possessing the capsular type $K_{1}$ antigen. The presence of sialic acid on the surface of these two bacteria $(5,6)$ has been suggested as a partial explanation for their virulence in neonates (7). However, each of the five serotype strains of group B streptococci (Ia, Ib, Ic, II, and III) contain sialic acid (8), yet only type III strains are regularly associated with meningitis.

A disparity exists between the rate of asymptomatic colonization of neonates at birth ( 92/1,000 live births) and the attack rate for symptomatic disease due to type III strains $(\sim 1.6 / 1,000$ live births $)(9,10)$. Several possible factors might influence risk for the development of symptomatic infection with type III strains of group B streptococci among infants. Of these, maternal antibody deficiency to a capsular polysaccharide antigen isolated from type III or- 
ganisms has been shown to be one significant variable (11). This report describes the quantitative determination of antibody to this antigen by means of a radioactive antigen-binding assay. The antibody concentration in sera from 31 infants and 4 parturients with invasive type III, group B streptococcal infection was determined by this assay. Earlier observations that low levels of maternal antibody are related to the development of invasive, symptomatic infection among neonates and infants are quantitated and extended, and evidence is presented that this antibody is transplacentally transferred.

\section{METHODS}

Preparation of hyperimmune antisera. New Zealand white rabbits were immunized with formalin-treated whole cell vaccines of prototype strains of group B Streptococcus (090-Ia, H36B-Ib, A909-Ic, 18RS21-II, and D136C-III) and type III strain, M732, isolated from an infant with meningitis. These methods previously have been described (6). Sera were stored at $-70^{\circ} \mathrm{C}$ in 1 to 2 -ml aliquots without preservatives until used.

Capsular antigen preparation. The polysaccharide antigen employed in both the quantitative precipitin analysis and the radioactive antigen-binding assay (RABA) ${ }^{1}$ was isolated and purified from a type III strain of group B Streptococcus by methods detailed elsewhere (6). Previous immunochemical investigation of type-specific antigens of group B Streptococcus have established that these polysaccharides contain acid-labile determinants $(6,13-15)$. It has been shown that growth of group B streptococci in standard Todd-Hewitt (Difco Laboratories, Detroit, Mich.) broth results in acid accumulation and glucose depletion during the $\log$ phase of growth (12). For these reasons, it was deemed preferable to modify Todd-Hewitt broth to insure isolation of "intact" surface antigens. Moreover, provision of a growth medium which makes glucose available to organisms during their entire growth cycle appeared to more closely correlate with conditions which occur during human infection.

Organisms were grown in Todd-Hewitt broth modified with additional quantities of disodium phosphate and glucose (12). The molecular size of the purified polysaccharide antigen extracted from organisms grown in the modified medium was estimated by gel filtration on a $2.5 \times 80-\mathrm{cm}$ column of Sepharose 4B (Pharmacia Fine Chemicals, Piscataway, N. J.). The void volume of the column was detected with blue dextran. Capillary precipitin tests of the fractions with type III-specific antiserum showed that the polysaccharide eluted at the void volume of the column. This indicates a molecular size $>5 \times 10^{6}$ daltons. The chemical composition of this antigen has been reported elsewhere (11), and is quite similar to that found for the purified "native" type III antigen isolated from organisms grown in standard glucose medium (6). The antigen extracted from organisms grown in excess glucose medium contains both the type III-specific and another serological determinant common to prototype strains, group B variant (090R), type Ia (090), type Ib (H36B), type Ic (A909), and type II (18RS21) as measured by precipitin reactions with hyperimmune rabbit antisera prepared to these strains. Repeated attempts to isolate the type III-specific determinant from this common

${ }^{1}$ Abbreviations used in this paper: RABA, radioactive antigen-binding assay. serological determinant by molecular-sieve chromatography, alcohol fractionation, polyacrylamide-gel electrophoresis, ionexchange chromatography, and affinity chromatography were unsuccessful. Furthermore, this polysaccharide is probably one molecule as indicated by the fact that all available antigen is bound to globulins when reacted with either type III-specific or group B-specific antisera, although the type III-specific antisera consistently react with much higher titers indicating the immunodominance of this determinant (11). However, the existence of two highly anionic interlinked polysaccharides remains a possibility.

Quantitative precipitin analysis. Quantitative precipitin analysis on five human sera was performed by the method of Gotschlich et al. (16).

RABA with intrinsically labeled antigen. Radioactive polysaccharide antigen was isolated from strain M732 grown in modified Todd-Hewitt broth supplemented with $5 \mathrm{mCi}$ of ${ }^{3} \mathrm{H}$-labeled sodium acetate/liter. The specific activity of the purified polysaccharide was equal to $2,000 \mathrm{cpm} / \mu \mathrm{g}$. The RABA reported by Farr (17), and modified by several investigators for the detection of antibody to the capsular polysaccharides of numerous organisms, was employed (16, $18,19)$. This method has been described in detail previously (11).

Mean antibody concentrations were recorded as the arithmetic mean of the percentage of binding of antigen in duplicate serum samples. Inasmuch as the percentage of binding was linearly related to the logarithm of the antibody concentration as determined by the method of least squares, the concentration of antibody could be determined from percentage of binding.

2-Mercaptoethanol reduction. Selected human sera were mixed with equal volumes of $0.2 \mathrm{M} 2$-mercaptoethanol (Eastman Kodak Co., Rochester, N. Y.) in phosphate buffer, $\mathrm{pH}$ 7.4 (20). Control saline dilutions of each serum were made and handled in an identical manner. All tubes were incubated at $24^{\circ} \mathrm{C}$ for $24 \mathrm{~h}$ in sealed tubes. The serum mixtures were then dialyzed in phosphate buffer for $24 \mathrm{~h}$ with three changes. Specimens were concentrated to the original volume in an ultrafiltration cell (Amicon Corp., Lexington, Mass.) using a PM-30 membrane. Treated and saline control sera were then tested in the RABA.

Study population. 31 infants with symptomatic, invasive group B streptococcal infection with type III strains, and 29 of their mothers were studied. Seven of these infants have been reported elsewhere (11). Serum specimens were collected from these infants and their mothers. These infants were hospitalized at Jefferson Davis and Ben Taub Hospitals, Houston, Tex. (14 patients), at Texas Children's Hospital, Houston, Tex. (10 patients), at Hermann Hospital, Houston, Tex. (1 patient), at Cambridge City Hospital, Cambridge, Mass. (2 patients), Boston City Hospital, Boston, Mass. (2 patients), Children's Memorial Hospital, Chicago, Ill. (1 patient), and at New York University Medical Center, New York (1 patient). Each of these infants had type III strains of group B Streptococcus isolated from blood, cerebrospinal fluid, joint, and (or) bone cultures. Of the infants with type III, group B streptococcal infections, 9 had onset during the first 5 days of life ("early onset type") and 22 had onset between the 9th day and 7th wk of life ("late onset type"). Acute sera from babies and mothers were obtained at a mean of 3.4 days after diagnosis and convalescent sera at a mean of 23.5 days after diagnosis.

Four women with group B streptococcal puerperal sepsis were also studied; two were hospitalized at Boston City Hospital, one at Cambridge City Hospital, and one at Jefferson Davis Hospital. Two of these women delivered asymptomatic neonates who had negative blood and spinal fluid 


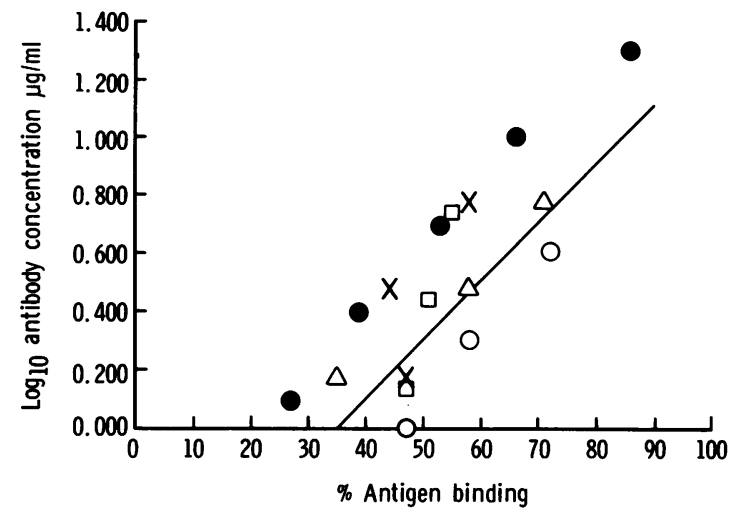

FIGURE 1 The antigen-binding capacity of dilutions of five human sera. The percent of intrinsically labeled ${ }^{3} \mathrm{H}$-type III capsular polysaccharide bound by antibody is plotted against the logarithm of the antibody concentration as determined by quantitative precipitation: $1, \bigcirc ; 2, \square ; 3, \times ; 4, \Delta ; 5,0$.

cultures, but were initially treated with antibiotics because of their mothers' illness. One of these women delivered a neonate with early-onset-type bacteremia associated with respiratory symptoms (K. J.), and another had twins who were well until 6 wk of age. At that time, one twin (J. A.) developed late-onset-type meningitis and the other (L. A.) had bacteremia without meningeal invasion. Serum from the woman with twins was collected during the acute phase of her infants' illness, but this was 6 wk after recovery from her own illness. She had a type III strain of group B Strepto- coccus isolated from a vaginal culture at the time of her babies' illness, but her blood culture isolate was not available for serotyping.

Pregnant women at the Boston City Hopsital were invited to participate in this study and written informed consent was obtained from those who agreed. Sera and vaginal cultures for the isolation of group B Streptococcus were collected from these women at intervals during pregnancy and at delivery. Sera from each of 43 type III vaginal carriers identified had antibody determinations performed. In addition, a random sample of sera from 12 type Ia, Ib, Ic, or II vaginal carriers as well as 16 women who had no group B streptococci isolated in at least three consecutive vaginal cultures were analyzed. Sera from 38 of these women collected on the day of delivery and cord sera from each of their babies were tested for the presence of antibody. These 38 mother-infant pairs were selected on the basis of availability of cord sera and concentration of maternal antibody. None of these women or their neonates developed symptomatic infection with group B Streptococcus during a 4-mo period of observation after delivery. Most of these neonates had cultures from external auditory canal, umbilicus, throat, and rectum obtained during the first 4 days of life examined for group B Streptococcus. All cultures were grown in a selective broth medium, and identification as well as serotyping of isolates was performed by techniques previously described (9). All sera were stored at $-20^{\circ} \mathrm{C}$ until tested.

Statistical methods. Differences between acute and convalescent sera were evaluated using a paired $t$ test (21). The Spearman rank correlation (22) was used to test the correlation between maternal and cord sera concentration. Antibody concentrations for mothers of infants with illness

TABLE I

Summary of Antibody Response in Patients with Invasive Type III, Group B Streptococcal Infection

\begin{tabular}{|c|c|c|c|c|c|}
\hline \multirow{2}{*}{$\begin{array}{c}\text { Group B streptococcal } \\
\text { disease }\end{array}$} & \multirow{2}{*}{$\begin{array}{l}\text { Mean age } \\
\text { at diagnosis }\end{array}$} & \multicolumn{2}{|c|}{$\begin{array}{l}\text { Median and range antibody } \\
\text { concentration }\end{array}$} & \multirow{2}{*}{$\begin{array}{c}\text { Mean difference in } \\
\text { acute vs. convalescent } \\
\text { sera antibody concn. } \$ \\
\text { (95\% confidence interval) }\end{array}$} & \multirow{2}{*}{$\begin{array}{l}\text { Significance } \\
\text { of mean } \\
\text { difference } \$\end{array}$} \\
\hline & & Acute & Convalescent* & & \\
\hline & & \multicolumn{2}{|c|}{$\mu g / m l$} & $\mu g / m l$ & \\
\hline I. Sepsis, bacteremia & 13.0 days & $\begin{array}{c}0.65 \\
(0.34-1.52) \\
n=8_{\|}\end{array}$ & $\begin{array}{c}1.43 \\
(0.72-2.60) \\
n=4\end{array}$ & $\begin{array}{l}0.59 \\
n=4\end{array}$ & NS \\
\hline II. Meningitis & 13.4 days & $\begin{array}{c}0.45 \\
(0.32-1.52) \\
n=16\end{array}$ & $\begin{array}{c}0.99 \\
(0.32-40.2) \\
n=10\end{array}$ & $\begin{array}{c}0.21 \\
(0.01-0.41) \\
n=9\end{array}$ & $P<0.05$ \\
\hline $\begin{array}{l}\text { III. Septic arthritis or } \\
\text { osteomyelitis }\end{array}$ & 30.8 days & $\begin{array}{c}1.05 \\
(0.33-1.78) \\
n=2\end{array}$ & $\begin{array}{c}39.2 \\
(17.8-40.2) \\
n=7\end{array}$ & $\begin{array}{c}33.46 \ddagger \\
(26.78-40.14) \\
n=5\end{array}$ & $P<0.01$ \\
\hline IV. Puerperal sepsis & $23.3 \mathrm{yr}$ & $\begin{array}{c}1.22 \\
(0.41-1.68) \\
n=3\end{array}$ & $\begin{array}{c}4.6 \\
(3.2-5.2) \\
n=4\end{array}$ & $\begin{array}{c}3.70 \\
(3.06-4.33) \\
n=3\end{array}$ & $P<0.01$ \\
\hline
\end{tabular}

* Sera obtained 7-63 days after diagnosis (mean, 23.5 days).

\$ Only two infants had acute sera available, but five had acute or early convalescent sera and these were used for calculations of differences.

$\S$ Paired $t$ test (21).

„n, number of patients. 
TABLE II

Bacteremia or Sepsis

\begin{tabular}{lcccc}
\hline & & \multicolumn{2}{c}{ Antibody concentration in sera } \\
\cline { 3 - 4 } & & \multicolumn{2}{c}{ Infants } \\
\cline { 3 - 4 } Patients & Age at diagnosis & Acute & Convalescent & Mothers \\
\hline & & & $\mu g / m l$ & \\
R. P. & 1 day & 0.74 & 2.60 & 0.44 \\
S. T. & 1 day & 1.52 & 1.78 & $12.00 \S$ \\
K. J. & 1 day & 1.28 & 1.18 & 1.22 \\
B. K. & 2 days & 1.08 & NAt & 1.52 \\
B. L. & 19 days & 0.56 & NA & 1.88 \\
S. K. & 21 days & 0.34 & NA & 1.36 \\
L. A. & 6 wk & 0.48 & NA & NA \\
J. S. & 7 wk & 0.40 & 0.72 & 0.90 \\
& & &
\end{tabular}

* Mother had puerperal sepsis with isolation of type III group B Streptococcus from blood culture.

$\$$ Not available.

$\S$ No detectable antibody after 2-mercaptoethanol reduction.

due to group B Streptococcus and well babies were compared with the Mann-Whitney U test (22).

\section{RESULTS}

Quantitative determination of antibody by precipitation and by radioactive antigen-binding capacity. To relate antigen-binding capacity to antibody concentration, the radioactive antigen-binding capacity of five human sera with known content of precipitating antibody was determined. The concentrations of antibody in these sera were determined by quantitative precipitation and were $8,11,10,12$, and $40 \mu \mathrm{g} / \mathrm{ml}$. The capacity of these sera and dilutions thereof to bind intrinsically labeled polysaccharide antigen was measured by the method of Farr (17). A significant linear relationship was observed between percent of antigen bound and the log of the antibody concentration (Fig. 1), $(y=0.0236[x]+[-0.8201], r$ $=0.86$ ).

Antibody in sera from sick infants. Quantitative antibody responses from four groups of infected infants or adults are summarized in Table I. The individual patient data are found in Tables II-VI. The median antibody concentrations in the acute sera of infants with sepsis, meningitis, and bone or joint infection were $0.65 \mu \mathrm{g} / \mathrm{ml}$ (range, $0.34-1.52 \mu \mathrm{g} / \mathrm{ml}$ ), $0.45 \mu \mathrm{g} / \mathrm{ml}$ (range, $0.32-1.52 \mu \mathrm{g} / \mathrm{ml}$ ), and $1.05 \mu \mathrm{g} / \mathrm{ml}$ (range, $0.334-$ $1.75 \mu \mathrm{g} / \mathrm{ml}$ ), respectively (Table I). Low concentrations of antibody to the capsular antigen were consistently found in the acute sera of infants who developed clinical illness due to type III strains of group B Streptococcus. Furthermore, the acute sera from three adults with puerperal sepsis (Table I) contained low levels of antibody to the "native" capsular antigen.
The median antibody concentration in the convalescent sera taken from four infants with sepsis or bacteremia due to type III, group B Streptococcus was $1.43 \mu \mathrm{g} / \mathrm{ml}$ (range, $0.72-2.60 \mu \mathrm{g} / \mathrm{ml}$ ). The mean rise in antibody concentration between paired acute and convalescent sera from infants with sepsis was 0.59 $\mu \mathrm{g} / \mathrm{ml}$ which was not significant (Table I).

The convalescent sera from 10 infants with meningitis had a median antibody concentration of 0.99 $\mu \mathrm{g} / \mathrm{ml}$ (range, $0.32-40.2 \mu \mathrm{g} / \mathrm{ml}$ ). The mean rise in antibody concentration between the paired acute and convalescent sera in this group was $0.21 \mu \mathrm{g} / \mathrm{ml}$ with a $95 \%$ confidence interval of $0.01-0.41 \mu \mathrm{g} / \mathrm{ml}(P<0.05)$ (Table I). The data from one patient (S. S.) was eliminated from the calculation of mean difference because this patient had an extremely large increase in convalescent serum antibody concentration which was different from all the other observations (26-fold greater than the next highest observation). Inclusion of this value would have unduly influenced the mean difference given the small number of subjects available.

The sera from five infants with osteomyelitis or septic arthritis were also studied for the development of anticapsular polysaccharide antibody. In these cases, either acute or early convalescent sera were compared to late convalescent sera. The median convalescent serum antibody concentration was 39.2 $\mu \mathrm{g} / \mathrm{ml}$ (range, $17.8-40.2 \mu \mathrm{g} / \mathrm{ml}$ ). The mean increase

TABLE III

Meningitis

\begin{tabular}{|c|c|c|c|c|}
\hline \multirow[b]{3}{*}{ Patients } & \multirow[b]{3}{*}{ Age at diagnosis } & \multicolumn{3}{|c|}{ Antibody concentration in sera } \\
\hline & & \multicolumn{2}{|c|}{ Infants } & \multirow[b]{2}{*}{ Mothers } \\
\hline & & Acute & Convalescent & \\
\hline & & & $\mu g / m l$ & \\
\hline B. Z. & 1 day & 0.38 & NA* $^{*}$ & 26.00 \\
\hline S. K. & 4 days & 0.52 & NA & 1.88 \\
\hline P. F. & 4 days & 0.58 & NA & 1.22 \\
\hline G. W. & 4 days & 0.68 & 1.28 & 0.90 \\
\hline $\mathrm{J} . \mathrm{T}$. & 5 days & 1.52 & 1.52 & 1.52 \\
\hline W. W. & 9 days & 0.38 & 0.32 & 0.41 \\
\hline B. R. & 11 days & 0.80 & NA & 1.52 \\
\hline S. W. & 12 days & 0.36 & NA & 0.56 \\
\hline E. D. & 14 days & 0.34 & 0.90 & 0.44 \\
\hline J. S. & 16 days & 0.94 & 1.08 & 0.62 \\
\hline M. H. & 17 days & 0.72 & 1.16 & 0.56 \\
\hline V. W. & 17 days & 0.38 & 0.38 & 0.46 \\
\hline A. A. & 17 days & 0.32 & 0.32 & 0.38 \\
\hline S. S. & 17 days & 0.36 & 40.20 & 0.64 \\
\hline J. M. & 18 days & 0.38 & 0.58 & 2.00 \\
\hline J. A.t & 6 wk & 0.56 & NA & NA \\
\hline
\end{tabular}

* Not available.

Mother had puerperal sepsis with isolation of type III group B Streptococcus from blood culture. 
TABLE IV

Septic Arthritis or Osteomyelitis

\begin{tabular}{|c|c|c|c|c|c|}
\hline \multirow[b]{2}{*}{ Patient } & \multirow[b]{2}{*}{ Age at diagnosis } & \multirow[b]{2}{*}{ Diagnosis } & \multicolumn{2}{|c|}{ Antibody in infant serum } & \multirow{2}{*}{$\begin{array}{c}\text { Antibody in } \\
\text { maternal serum }\end{array}$} \\
\hline & & & Acute & Convalescent & \\
\hline & & & & $\mu g / m l$ & $\mu \mathrm{g} / \mathrm{ml}$ \\
\hline E. D. & 20 days & $\begin{array}{l}\text { Septic } \\
\text { arthritis }\end{array}$ & 1.78 & $6.0(14), 40.2(26) \ddagger$ & 0.52 \\
\hline M. R. & 21 days & Osteomyelitis & NA* & $3.2(10), 27.6(36)$ & 1.28 \\
\hline B. $\mathbf{R}$. & 24 days & $\begin{array}{l}\text { Septic } \\
\text { arthritis }\end{array}$ & NA & $40.2(16)$ & 0.56 \\
\hline G.M. & 25 days & Osteomyelitis & 0.334 & $36.2(59)$ & 0.42 \\
\hline B. B. & 28 days & $\begin{array}{l}\text { Septic } \\
\text { arthritis }\end{array}$ & NA & $23.4(24)$ & 0.90 \\
\hline C. $\mathrm{K}$. & $7 \mathrm{wk}$ & Osteomyelitis & NA & $\begin{array}{l}6.8(7), 17.8(19) \\
\quad 40.2(32)\end{array}$ & 1.88 \\
\hline M. M. & $7 \mathrm{wk}$ & Osteomyelitis & NA & $3.0(13), 38.2(24)$ & 1.60 \\
\hline
\end{tabular}

in antibody concentration between acute and convalescent sera was $33.46 \mu \mathrm{g} / \mathrm{ml}$ with a $95 \%$ confidence interval of $26.78-40.14 \mu \mathrm{g} / \mathrm{ml}(P<0.01)$.

Sera from women with puerperal sepsis. Sera from four adult women with group B streptococcal puerperal sepsis were also studied (Table I). The median antibody concentrations in their acute and convalescent sera were $1.22 \mu \mathrm{g} / \mathrm{ml}$ (range, 0.41-1.68 $\mu \mathrm{g} / \mathrm{ml}$ ) and $4.6 \mu \mathrm{g} / \mathrm{ml}$ (range, $3.2-5.2 \mu \mathrm{g} / \mathrm{ml}$ ), respectively. The mean rise in antibody concentration between the three available acute and convalescent paired sera was $3.78 \mu \mathrm{g} / \mathrm{ml}$ with a $95 \%$ confidence interval of $3.06-4.33 \mu \mathrm{g} / \mathrm{ml}(P<0.01)$.

Antibody prevalence in women delivering healthy and sick infants. Fig. 2 demonstrates the prevalence of antibody in sera from two groups of women: (I) 29 women whose infants developed serious type III, group B streptococcal disease; (II) 43 women with type

TABLE V

Puerperal Sepsis

\begin{tabular}{lccc}
\hline & & \multicolumn{2}{c}{ Antibody concentration in serum } \\
\cline { 3 - 4 } Patient & Age & Acute & Convalescent \\
\hline & $y r$ & \multicolumn{2}{c}{$\mu g / m l$} \\
E. E. & $24 \mathrm{yr}$ & 1.68 & 5.2 \\
S. J. & $28 \mathrm{yr}$ & 1.22 & 4.8 \\
M. A. & $21 \mathrm{yr}$ & NA* & 3.2 \\
B. E. & $18 \mathrm{yr}$ & 0.41 & 4.4 \\
\hline
\end{tabular}

* Not available.

† Collected 15-63 days after diagnosis (mean, 37 days).
III strains of group B Streptococcus isolated from vaginal cultures during pregnancy who delivered healthy neonates who did not become ill. The women whose babies became ill had significantly less ( $P$ $<0.001$, Mann-Whitney $U$ test) antibody in their sera than those whose babies remained healthy. These data confirm an earlier report indicating that low levels of maternal antibody correlate with neonatal susceptibility to serious group B streptococcal infection (11).

Transplacental passage of antibody. Paired maternal and infant sera were obtained from 62 mothers and their neonates. 24 of these serum pairs were collected from sick infants and their mothers (Tables II, III, IV). The remaining 38 (Table VI) were obtained from selected women delivering healthy neonates. 10 of these 38 women had type III, group B Streptococcus isolated from vaginal cultures during pregnancy. 12 of these 38 women had vaginal colonization with strains of group B Streptococcus other than type III, and an additional 16 women had no group B streptococci isolated from vaginal cultures. A significant correlation $(P<0.01)$ was found to exist between the antibody concentration of maternal-cord sera pairs ( $r=0.76$, Spearman rank correlation) and of all 62 maternal-infant sera $(r=0.69)$, Spearman rank correlation). These data indicate that neonatal antibody can be estimated from the maternal antibody level, but that additional factors may be important in determining precise concentration of antibody, in this instance, immunoglobulin class.

The hypothesis that nontransplacentally transferred immunoglobulins (IgM) were at least in part responsible for the finding of high levels of antibody in the 
serum of mothers whose infants had low levels of antibody was tested by studying the effect of 2mercaptoethanol reduction on the maternal serum of patient S. T. (Table II). Treatment with 2-mercaptoethanol led to a fall in antibody concentration from a pretreatment concentration of 12 to $1.0 \mu \mathrm{g} / \mathrm{ml}$, indicating that the low level of antibody in this woman's infected infant resulted from failure of transplacental passage of IgM.

\section{DISCUSSION}

The polysaccharide antigen extracted from a type III strain of group B Streptococcus grown in a modified Todd-Hewitt broth may closely resemble that which the naturally infected host recognizes immunologically. This antigen is extracted by a "gentle" method and results in a more complete molecule than that extracted by methods employing heat and acid (6). Furthermore, it is isolated from organisms grown in an optimal environment of neutral $\mathrm{pH}$ and sufficient glucose. It has been demonstrated that the type III polysaccharide antigen has an acid-heat labile determinant when extracted from organisms grown in a buffered Todd-Hewitt broth which is glucose limiting (6). However, organisms grown in medium with excess glucose have increased quantities of extractable capsular polysaccharide and increased cell wall thickness as determined by electron microscopy (12). This medium more closely simulates that glucose content available in natural human infection. The capsular polysaccharide isolated from this medium is more broadly reactive serologically as indicated by its ability to precipitate with both type III-specific antiserum and antisera with group B and other type specificities (11). Numerous attempts to immunochemically separate these two serological determinants have been unsuccessful. Further evidence that this capsular antigen represents the cell surface polysaccharide of type III, group B Streptococcus is derived from an opsonophagocytic assay with type III organisms. This capsular polysaccharide completely inhibits opsonization of homologous and heterologous type III strains by type III-specific antisera at a concentration of $<1.0$ $\mu \mathrm{g} / \mathrm{ml}(23)$.

The RABA developed by Farr is a useful method for the quantitative determination of low concentrations of antibody (17). The quantity of antigen bound by a serum is a direct function of the concentration of antibody in that serum and the affinity of this antibody for antigen. In this investigation, the RABA was standardized by reference to antisera with known content of precipitating antibody. The degree of antigen binding was converted to antibody concentration with full recognition of the possible errors resulting from this conversion (16). The method of least
TABLE VI

Maternal-Cord Pairs

\begin{tabular}{|c|c|c|}
\hline $\begin{array}{l}\text { Serotype of group } \\
\text { B Streptococcus in } \\
\text { colonized mothers }\end{array}$ & $\begin{array}{l}\text { Mothers' serum } \\
\text { antibody } \\
\text { concentration }\end{array}$ & $\begin{array}{c}\text { Cord serum } \\
\text { antibody } \\
\text { concentration }\end{array}$ \\
\hline & $\mu g / m l$ & $\mu g / m l$ \\
\hline II & 0.350 & 0.338 \\
\hline Neg. & 0.396 & 0.376 \\
\hline Neg. & 0.418 & 0.338 \\
\hline Neg. & 0.441 & 0.418 \\
\hline Neg. & 0.468 & 0.418 \\
\hline Ic & 0.484 & 0.484 \\
\hline Neg. & 0.522 & 0.418 \\
\hline II & 0.522 & 0.318 \\
\hline Neg. & 0.522 & 0.984 \\
\hline Neg. & 0.550 & 0.520 \\
\hline Ib & 0.584 & 0.350 \\
\hline Neg. & 0.584 & 0.338 \\
\hline Neg. & 0.584 & 0.368 \\
\hline III & 0.584 & 0.804 \\
\hline Neg. & 0.612 & 0.468 \\
\hline III & 0.648 & 0.386 \\
\hline Neg. & 0.722 & 0.396 \\
\hline Neg. & 0.722 & 0.350 \\
\hline Neg. & 0.850 & 0.584 \\
\hline Ic & 0.896 & 0.468 \\
\hline II & 1.000 & 0.522 \\
\hline Neg. & 1.032 & 0.762 \\
\hline II & 1.216 & 1.430 \\
\hline Neg. & 1.216 & 0.804 \\
\hline Neg. & 1.430 & 0.376 \\
\hline II & 1.920 & 0.584 \\
\hline III & 4.100 & 6.700 \\
\hline III & 17.820 & 3.780 \\
\hline II & 18.810 & 5.400 \\
\hline III & 19.880 & 2.960 \\
\hline II & 22.160 & 8.800 \\
\hline III & 23.380 & 7.080 \\
\hline III & 24.700 & 4.100 \\
\hline Ib & 34.220 & 4.580 \\
\hline II & 38.140 & 40.200 \\
\hline III & 40.200 & 27.540 \\
\hline III & 40.200 & 36.120 \\
\hline III & 40.200 & 40.200 \\
\hline
\end{tabular}

squares provides a reasonable description of the relationship between percent binding and $\log _{10}$ antibody concentration $\left(r^{2}=0.75\right)$.

Low concentrations of antibody to the capsular polysaccharide were consistently detected in the acute sera of infants and adults who developed clinical illness due to type III strains of group B Streptococcus. Study of convalescent serum antibody in these patients suggested that both age and pathological expression of disease (i.e. meningitis vs. osteomyelitis) influence antibody response. The mean rise in serum antibody between paired acute and convalescent speci- 


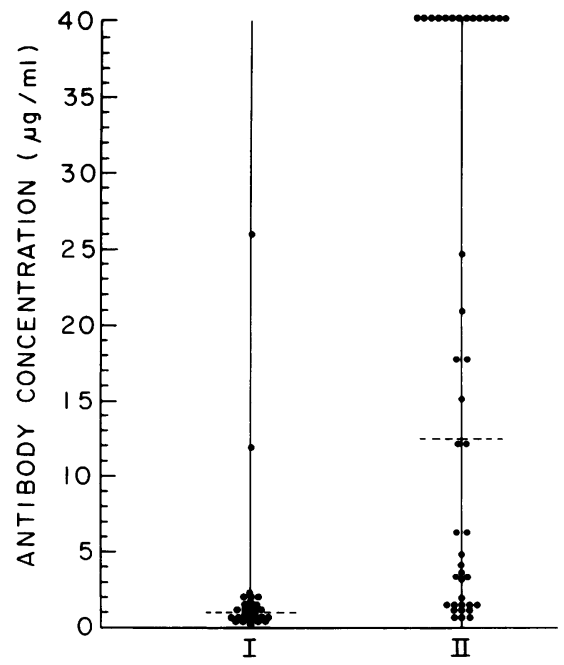

FIGURE 2 The concentration of antibody found (I) in the sera of 29 women whose infants developed serious illness due to type III, group B Streptococcus and (II) in the sera of 43 women who were vaginal carriers of type III strains but whose infants remained healthy. (---, median).

mens was highly significant for adults with sepsis and infants with bone or joint infection, suggesting that natural infection does result in the production of serum antibody. However, whereas adults with bloodstream invasion developed significant rises in serum antibody upon recovery, this was not observed among young infants with sepsis or bacteremia. This observation may be due to the small number of infants studied, but the magnitude of the response in similar infections occurring in adults vs. infants obviously differs (Table I, groups I and IV). These observations regarding the influence of age on antibody response to disease may be analogous to that reported among patients with exposure to either natural infection or immunization with capsular polysaccharides of Hemophilus influenzae, type $\mathrm{b}$, and groups $\mathrm{A}$ and $\mathrm{C}$ meningococci. Young infants with serious $H$. influenzae, type $b$ infection often fail to have antibody detected in convalescent sera (24). Similarly, the correlation of antibody response to polyribophosphate with age and dose has been previously documented; children under $1 \mathrm{yr}$ of age have no or limited immunological response to this preparation (19). However, both polyribophosphate and purified groups A and $\mathrm{C}$ meningococcal polysaccharides are immunogenic in adults when given as purified vaccines or when the exposure is through natural infection (25-27).

Those infants with meningeal invasion demonstrated significant rises in median antibody concentration upon recovery although the levels were considerably lower than those among infants of similar age with bone or joint infection. Thus, the difference between the response of infants to bacteremia alone, meningitis, and bone or joint disease may be related to differences in total antigenic stimulation as a function of exposure and (or) quantity, or to genetically determined immunocompetence. The latter has been suggested by Whisnant et al. (28) as an important factor in the immune response to $H$. influenzae, type $\mathrm{b}$ infections. If one controls for age, patients with disease manifested as meningitis have quite different serum antibody responses than do those with epiglottitis (28).

Median concentration of antibody in groups of healthy infants, children, and women of childbearing age appears to be age dependent (29). In a recent survey, sera were collected from 12 infants who were 2-12-mo-old, from 29 children who were 2-5-yr-old, and from 33 children who were 6-15-yr-old. The median antibody concentrations in these groups were $0.444 \mu \mathrm{g} / \mathrm{ml}(0.356-0.684$, range), $0.468 \mu \mathrm{g} / \mathrm{ml}(0-16.9$, range), and $0.648 \mu \mathrm{g} / \mathrm{ml}(0-29.0$, range), respectively. A median concentration of antibody similar to that reported in these older children has been detected in the sera of 65 women age 17-35 yr (median, $0.522 \mu \mathrm{g} / \mathrm{ml}$, range, $0.338-40.3 \mu \mathrm{g} / \mathrm{ml}$ ). Although these median levels indicate that increasing concentration of antibody is influenced by increasing age, the range indicates that individuals with very low levels of antibody exist in any given age group (29). ${ }^{2}$

The absolute concentration of antibody necessary for protection against group B streptococcal disease has not been determined. The quantitation reported here appears more useful in defining the lower limits of sensitivity of this assay as well as changes in antibody concentration than the arbitrary $40 \%$ binding reported in a previous study (11). However, the data reported for investigations of group $\mathrm{A}$ and group $\mathrm{C}$ meningococcal vaccines in infants and children given $50 \mu \mathrm{g}$ of group A meningococcal polysaccharide developed $9-24 \mu \mathrm{g} / \mathrm{ml}$ of anti-A antibody as determined by RABA, and this level was proven to be $100 \%$ protective for up to $2 \mathrm{yr}$ (30). Gold et al. (31) reported that anti-A antibody concentrations of $2-4 \mu \mathrm{g} / \mathrm{ml}$ were induced by booster immunization in 7- and 12mo-old infants. A recent field trial in Finland has established the efficacy of similar levels of antibody in protection against group A meningococcal disease among children 3 mo-5 yr of age (32). Immunization of infants with 5,25 , or $100 \mu \mathrm{g}$ of group C meningococcal vaccine has resulted in mean anti-C antibody concentrations of $0.11 \mu \mathrm{g} / \mathrm{ml}$ in 3-mo olds given the lowest dose, and $2.6 \mu \mathrm{g} / \mathrm{ml}$ in 12 -mo olds given the highest dose (31). These authors questioned the protective efficacy of these levels of antibody because no protection was apparent in Brazilian infants 6-23 mo of age immunized with group C

${ }^{2}$ Baker, C. J. Unpublished data. 
meningococcal vaccine during a recent epidemic of meningitis (33).

In the present investigation, it has been demonstrated that women with low levels of antibody to capsular polysaccharide antigen isolated from type III, group B Streptococcus deliver infants who have a statistically significant increased risk for the development of clinical infection with type III strains of group B streptococci. However, prospective studies to identify the precise attack rate for disease among infants born to mothers with low levels of antibody have not been performed. It is quite likely that other host factors besides maternal antibody deficiency are related to the pathogenesis of these infections and to the unique susceptibility of infants less than 3 mo of age to disease.

Although the method employed in this investigation, a RABA, can detect antibody of all immunoglobulin classes $(17,20)$, it appears that the majority of pregnant women studied in this selected population had primarily serum IgG antibody directed against capsular polysaccharide of type III, group B Streptococcus. The methods used for selection invalidate any correlation between antibody concentration and colonization status in these women. The statistically significant correlation between the antibody concentration in matched maternal-cord serum pairs was not $100 \%$ which probably relates to immunoglobulin class of antibody in some mothers. However, it seems valid to accept low concentration of antibody in maternal serum as one risk factor for the development of infant disease with type III, group B Streptococcus. Development of serologic assays specific for IgG antibody in human sera (i.e. solid-phase radioimmunoassay or enzyme-linked immunoabsorbant assay technique) would allow more precise definition of women whose offspring are at significant risk for disease.

\section{ACKNOWLEDGMENTS}

We are indebted to Doctors Mark Goldstein, A. Todd Davis, Anne Gershon, and Larry Pickering, as well as the members of the Pediatric Housestaff at the Baylor Affiliated Hospitals in Houston, Tex. for contributing sera from some of these patients. We gratefully acknowledge Ms. Bette J. Webb for skilled technical assistance.

This research was supported by U. S. Public Health Service Fellowship AIO2305, grants AI12381 and AI13249 from the National Institute of Allergy and Infectious Diseases, and grant HD03693 from the National Institute of Child Health and Human Development.

\section{REFERENCES}

1. Franciosi, R. A., J. D. Knostman, and R. A. Zimmerman. 1973. Group B streptococcal neonatal and infant infections. J. Pediatr. 83: 707-719.
2. Baker, C. J., F. F. Barrett, R. C. Gordon, and M. D. Yow. 1973. Suppurative meningitis due to streptococci of Lancefield group B: a study of 33 infants. J. Pediatr. 82: 724729.

3. Wilkinson, H. W., R. R. Facklam, and E. C. Wortham. 1973. Distribution by serologic type of group B streptococci isolated from a variety of clinical material over a five-year period (with special reference to neonatal sepsis and meningitis). Infect. Immun. 8: 228-235.

4. Baker, C. J. and F. F. Barrett. 1974. Group B streptococcal infections in infants. The importance of various serotypes. J. Amer. Med. Assoc. 230: 1158-1160.

5. Kasper, D. L., J. L. Winkelhake, W. D. Zollinger, B. L. Brandt, and M. S. Artenstein. 1973. Immunochemical similarity between polysaccharide antigens of Escherichia coli 07: $\mathrm{K}_{1}$ (L) $\mathrm{NM}$ and group B Neisseria meningitidis. J. Immunol. 110: 262-268.

6. Baker, C. J., D. L. Kasper, and C. E. Davis. 1976. Immunochemical characterization of the "native" type III polysaccharide of group B Streptococcus. J. Exp. Med. 143: 258-270.

7. Robbins, J. B., G. H. McCracken, Jr., E. C. Gotschlich, F. Фrskov, I. Фrskov, and L. A. Hanson. 1974. Escherichia coli $\mathrm{K}_{1}$ capsular polysaccharide associated with neonatal meningitis. N. Engl. J. Med. 290: 1216-1220.

8. Baker, C. J. and D. L. Kasper, 1976. Identification of sialic acid in polysaccharide antigens of group B Streptococcus. Infect. Immun. 13: 284-288.

9. Baker, C. J. and F. F. Barrett. 1973. Transmission of group B streptococci among parturient women and their neonates. J. Pediatr. 83: 919-925.

10. Aber, R. C., N. Allen, J. T. Howell, H. W. Wilkinson, and R. R. Facklam. 1976. Nosocomial transmission of group B streptococci. Pediatrics. 58: 346-353.

11. Baker, C. J. and D. L. Kasper. 1976. Correlation of maternal antibody deficiency with susceptibility to neonatal group B streptococcal infection. N. Engl. J. Med. 294: $752-756$.

12. Baker, C. J. and D. L. Kasper. 1976. Microcapsule of type III strains of group B Streptococcus: production and morphology. Infect. Immun. 12: 189-194.

13. Lancefield, R. C. and E. H. Freimer. 1966. Typespecific polysaccharide antigens of group B streptococci. J. Hyg. 64: 191-203.

14. Freimer, E. H. 1967. Type-specific polysaccharide antigens of group B streptococci. II. The chemical basis for serological specificity of the type II $\mathrm{HCl}$ antigen. J. Exp. Med. 125: 381-392.

15. Wilkinson, H. W. 1975. Immunochemistry of purified polysaccharide type antigens of group B streptococcal types Ia, Ib, and Ic. Infect. Immun. 11: 845-852.

16. Gotschlich, E. C., M. Rey, R. Triau, and K. J. Sparks. 1972. Quantitative determination of the human immune response to immunization with meningococcal vaccines. J. Clin. Invest. 51: 89-96.

17. Farr, R. S. 1958. A quantitative immunochemical measure of the primary interaction between I*BSA and antibody. J. Infect. Dis. 103: 239-262.

18. Kabat, E. A. and A. E. Bezer. 1958. The effect of variation in molecular weight on the antigenicity of dextran in man. Arch. Biochem. Biophys. 78: 306-318.

19. Smith, D. H., G. Peter, D. L. Ingram, A. L. Harding, and P. Anderson. 1973. Responses of children immunized with the capsular polysaccharide of Hemophilus influenzae, type b. Pediatrics. 52: 637-644.

20. Grubb, R. and B. Swahn. 1958. Destruction of some agglutinins but not of others by two sulfhydryl compounds. Acta. Pathol. Microbiol. Scand. 43: 305-309. 
21. Hill, A. B. 1971. Principles of Medical Statistics. Oxford University Press, Inc., New York. 9th edition. 390 pp.

22. Snedecor, G. W. and W. G. Cochran. 1967. Statistical Methods. Iowa State University Press, Ames, Iowa. $593 \mathrm{pp}$.

23. Baltimore, R. S., D. L. Kasper, C. J. Baker, and D. K. Goroff. 1976. Opsonophagocytic antibody and immunity to type III strains of group B streptococci. Pediatr. Res. 10: 395 .

24. Norden, C. W., M. Melish, J. C. Overall, Jr., and J. Baum. 1972. Immunologic responses to Hemophilus influenzae meningitis. J. Pediatr. 80: 209-214.

25. Anderson, P., G. Peter, R. B. Johnston, Jr., L. H. Wetterlow, and D. H. Smith, 1972. Immunization of humans with polyribophosphate, the capsular antigen of Hemophilus influenzae, type b. J. Clin. Invest. 51: 31-39.

26. Goldschneider, I., M. L. Lepow, and E. C. Gotschlich. 1972. Immunogenicity of the group A and group C meningococcal polysaccharides in children. J. Infec. Dis. 125: 509-519.

27. Goldschneider, I., E. C. Gotschlich, and M. S. Artenstein. 1969. Human immunity to the meningococcus. II. Development of natural immunity. J. Exp. Med. 129: 1327-1348.

28. Whisnant, J. K., G. N. Rogentine, M. A. Gralnick, J. J. Schlesselman, and J. B. Robbins. 1976. Host factors and antibody response in Hemophilus influenzae type b meningitis and epiglottits. J. Infec. Dis. 133: 448-455.

29. Hammerschlag, M. R., S. Alpert, C. J. Baker, I. Rosner, and W. M. McCormack. 1976. Colonization with group B streptococci in girls under 16 years of age. Proceedings of the 16th Interscience Conference on Antimicrobial Agents and Chemotherapy. (Abstr.)

30. Wahdan, M. H., F. Rizk, A. M. El-Akkad, A. A. El Ghoroury, R. Hablas, N. I. Girgis, A. Amer, W. Boctar, J. E. Sippel, E. C. Gotschlich, R. Triau, W. R. Sanborn, and B. Cvjetanović. 1973. A controlled field trial of a serogroup A meningococcal polysaccharide vaccine. Bull. W. H. O. 48: 667-673.

31. Gold, R. C., M. L. Lepow, I. Goldschneider, T. L. Draper, and E. C. Gotschlich. 1975. Clinical evaluation of group $A$ and group $C$ meningococcal polysaccharide vaccines in infants. J. Clin. Invest. 56: 1536-1547.

32. Makela, P. H. 1977. Serum antibody response and protective effect of meningococcal group $\mathrm{A}$ and Hemophilus influenzae type b polysaccharides. J. Infect. Dis. In press

33. Taunay, A. de E., P. A. Galvao, J. S. de Morais, E. C. Gotschlich, and R. A. Feldman. 1974. Disease prevention by meningococcal serogroup $\mathrm{C}$ polysaccharide vaccine in preschool children: Results after eleven months in Sao Paulo, Brazil. Pediatr. Res. 8: 429. (Abstr.) 